\title{
ANALISIS NILAI SEMESTER GENAP MATA PELAJARAN BIOLOGI KELAS XI BERBASIS ONLINE DI SMA NEGERI 1 DAN SMA NEGERI 2 UNGGULAN TALANG UBI
}

\author{
Prihastiningthyas Risky Ajeng ${ }^{1}$ \\ Aseptianova ${ }^{2}$ \\ Ade Kartika ${ }^{3}$ \\ Meli Astriani ${ }^{*}$ \\ 1,2,3) Program Studi Pendidikan Biologi Universitas Muhammadyah Palembang \\ 4) Program Studi Pascasarjana Pendidikan Biologi, Universitas Muhammadiyah Palembang \\ E-mail: 4"meliastriani.g201@gmail.com
}

\begin{abstract}
Assessment of learning outcomes from the cognitive aspect can be seen from the minimum completeness criteria (KKM) values that have been set by schools and nationally. The purpose of this study was to determine the value analysis of biology subjects in the even semester of class XI students in SMA Negeri 1 and SMA Negeri 2 Unggulan Talang Ubi. This research method uses descriptive qualitative to find information and data analysis of student learning outcomes class XI. The research sample consisted of 4 teachers, 136 students of SMA Negeri 1 Talang Ubi, and 70 students of SMA Negeri 2 Unggulan Talang Ubi. Data collection using triangulation techniques with interviews, observation, and documentation. Data analysis used frequency descriptions with the help of SPSS version 22.0. The results of this study obtained the following data: (1) the average score of biology even semester at SMA Negeri 1 Talang Ubi is 75.56, which means that it has reached the school and national KKM. (2) the average score of biology even semester in SMA Negeri 2 Unggulan Talang Ubi has not reached the school and national KKM. These results can be caused by factors: 1) learning methods, 2) the number of meetings (duration of learning), 3) types of questions given by the teacher. It is hoped that in the future this research can improve the quality of learning during a pandemic.
\end{abstract}

Kata kunci: analisis nilai, berbasis online, Pelajaran biologi

\section{PENDAHULUAN}

Hasil belajar merupakan tujuan proses yang terdiri dari tiga ranah yaitu kognitif, afektif, dan psikomotor (Nurbudiyani, 2013). Ranah kognitif berhubungan dengan kemampuan intektual siswa yang menjadi kunci keberhasilan dalam proses pembelajaran. Ranah afektif berhubungan dengan sikap, nilai, minat, motivasi, dan apresiasi siswa. Ranah psikomotor berhubungan dengan keterampilan-keterampilan yang dimiliki setiap individu (Prasetya, 2012). Dari ketiga ranah tersebut, ranah kognitif adalah yang mencakup kegiatan mental (otak) seperti kemapuan berpikir, memahami, menghapal, mengaplikasi, menganalisa, mensintesa, dan kemampuan mengevaluasi (Nurbudiyani, 2013). Menurut Yunanti (2016) hasil belajaar pesera didik dapat dikatakan mencapai ketuntasan apabila peserta didik secara sadar mampu mengontrol proses kognitifnya secara berkesinambungan dan dampak pada peningkatan kemampuan metakognitif yang terkait dalam kedewasaan dan kemandirian pada saat belajar.

Penilaian hasil belajar oleh satuan pendidikan bertujuan menilai pencapaian Standar Kompetensi Lulusan untuk semua mata pelajaran dengan mempertimbangkan hasil penilaian peserta didik oleh pendidik (Novianti, 2020). Penilaian hasil belajar pada Kurikulum 2013 ini dilakukan oleh pendidik dan satuan pendidik melalui tahapan mengkaji silabus sebagai acuan perencanaan penilaian, pembuatan kisi-kisi instrumen dan penetapan kriteria penilaian, pelaksanaan penilaian dalam proses pembelajaran, menganalisis hasil penilaian 
dan memberi tindak lanjut atas penilaian yang dilakukan oleh pendidik, menyusun laporan hasil penilaian dalam bentuk deskripsi pencapaian kompetensi dan deskripsi sikap (Sari, 2011).

Berdasarkan hasil wawancara kepada guru mata pelajaran biologi yang telah dilakukan pada tanggal 23 Juni 2020 bahwa hasil penilaian Ujian Akhir Semester (UAS) pada saat belajar online di SMA Negeri 1 dan SMA Negeri 2 Unggulan Talang Ubi masih ada peserta didik yang memperoleh nilai di bawah Kriteria Ketuntasan Minimal (KKM) sekolah dan nasional. Hal ini menandakan bahwa terdapat permasalahan yang perlu dianalisis oleh guru menurut Friatma (2017) ada beberapa kemungkinan berkaitan dengan hal di atas yakni: 1) soal yang disusun terlalu sulit, 2) soal yang disusun kurang mengacu pada subtansi atau materi yang telah diajarkan, 3) pembelajaran yang dilakukan guru belum bisa dipahami oleh peserta didik dengan baik.

Hasil menyarankan bahwa wawancara dengan peserta didik menunjukan nilai UAS belum mencapai KKM dikarenakan pola mengajar yang bersifat teacher centered learning, terpaku pada buku serta penyajian materi yang bersifat monoton sehingga membuat peserta didik jenuh dan tidak dapat fokus terhadap pembelajaran yang sedang berlangsung. Oleh karena itu, perlu dilakukan penelitian menganalisis nilai semester genap mata pelajaran biologi kelas XI di SMA Negeri 1 Talang Ubi dan SMA Negeri 2 Unggulan Talang Ubi.

\section{METODE}

Penelitian ini dilaksanakan di SMA Negeri 1 dan di SMA Negeri 2 Unggulan Talang Ubi dengan menggunakan rancangan penelitian deskriptif kuantitatif yang dilakukan untuk mencari informasi dan data untuk mendeskripsikan kualitatif tes hasil nilai UAS peserta didik. Waktu pelaksanaan penelitian dilakukan mulai bulan Juni hingga Agustus 2020. Subjek penelitian ini adalah siswa kelas XI MIPA 1, XI MIPA 2, XI MIPA 3, dan XI MIPA 4 di SMA Negeri 1 Talang Ubi serta siswa kelas XI MIPA 1 dan XI MIPA 2 di SMA Negeri 2 Unggulan Talang Ubi.

Dalam penelitian ini menggunakan teknik pengumpulan data seperti: a) observasi yang dilakukan untuk mengetahui keadaan sekolah mengenai terkait sarana dan prasarana pada saat pembelajaran online, kegiatan inti, dan penutup saat pelajaran selesai, b) wawancara terbuka yang dilakukan untuk memperoleh informasi terkait pembelajaran metode, strategi pembelajaran, model pembelajaran, dan aplikasi dalam pembelajaran online, c) dokumentasi dilakukan untuk mengumpulkan data yang berupa daftar nilai ulangan akhir semester genap peserta didik, soal ulangan akhir semester genap dari guru mata pelajaran biologi, kisi-kisi soal dan jawaban.

Pada penelitian ini menggunakan analisis data program SPSS (Statistical Product Service Solution) menggunakan rumus Deskripsi Frekuensi berupa daftar, tabel, atau diagram yang menunjukan frekuensi atau jumlah berbagai kejadian dalam suatu sampel nilai dalam kelompok tersebut.

Menurut Hikmah (2016) mengatakan bahwa untuk mengetahui ketuntasan persentase yang menggambarkan hasil belajar siswa menggunakan rumus :

Keterangan:

$$
\text { Persentase }(\%)=\frac{f}{N} \times 100 \%
$$

$\mathrm{f}=$ Jumlah skor siswa

$\mathrm{N}=$ Jumlah siswa

\section{HASIL}

Rekapitulasi data rata-rata hasil nilai peserta didik yang berdasarkan nilai semester genap kelas XI di SMA Negeri 1 Talang Ubi dan SMA Negeri 2 Unggulan Talang Ubi, yang dilihat dari data Deskripsi Frekuensi dan data statistik dari sekolah pada Tabel-tabel berikut: 


\section{A. Data Deskripsi Frekuensi dan Distribusi Frekuensi Kelas XI SMA Negeri 1 Talang Ubi}

Hasil nilai gabungan dari yang terendah yaitu 25 hingga tertinggi yaitu 98 yang diambil pada semester genap kelas XI di SMA Negeri 1 Talang Ubi dari kelas XI MIPA 1, XI MIPA 2, XI MIPA 3, dan XI MIPA 4 yang disajikan pada Gambar 1 .

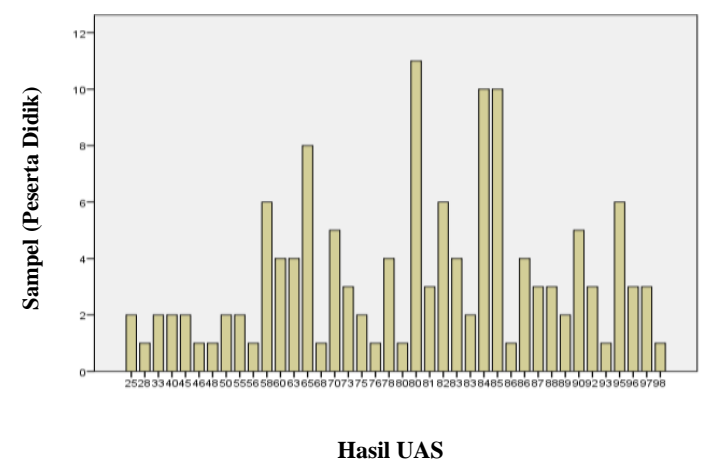

Gambar 1. Hasil Nilai Gabungan Dari Kelas XI MIPA 1, XI MIPA 2, XI MIPA 3, dan XI MIPA 4

Berdasarkan Gambar 1 menunjukan bahwa nilai biologi kelas XI MIPA 1, XI MIPA 2, XI MIPA 3, dan XI MIPA 4 di SMA Negeri 1 Talang Ubi berada dalam kategori sudah mencapai ketuntasan yang dibuktikan dengan peroleh nilai 25 hingga 98. Nilai paling rendah yaitu 25 sebanyak 2 orang, sedangkan nilai yang paling tinggi yaitu 98 sebanyak 1 orang. Nilai yang paling banyak di peroleh peserta didik yaitu 80 sebanyak 11 orang.

Jika dilihat distribusi frekuensi menunjukan hasil nilai semester genap dilihat pada Tabel 1 sebagai berikut.

Tabel 1. Distribusi Frekuensi Hasil Nilai Semester Kelas XI SMA Negeri 1 Talang Ubi

\begin{tabular}{|c|c|c|c|}
\hline No & Frekuensi & $\begin{array}{c}\text { Persentase } \\
(\mathbf{\%})\end{array}$ & Keterangan \\
\hline 1 & 98 siswa & 72,05 & Tuntas \\
& & & KKM \\
& & & Sekolah \\
\hline 2 & 89 siswa & 65,44 & $\begin{array}{c}\text { Tuntas } \\
\text { KKM } \\
\text { Nasional }\end{array}$ \\
\hline
\end{tabular}

\begin{tabular}{|c|c|c|c|}
\hline 3 & 16 siswa & 11,78 & $\begin{array}{c}\text { Belum } \\
\text { Tuntas } \\
\text { KKM } \\
\text { Sekolah }\end{array}$ \\
\hline 4 & 25 siswa & 18,38 & $\begin{array}{c}\text { Belum } \\
\text { Tuntas } \\
\text { KKM } \\
\text { Nasional }\end{array}$ \\
\hline
\end{tabular}

Berdasarkan Tabel 1 menyatakan bahwa hasil distribusi frekuensi yang tuntas nilai KKM sekolah dengan interval 67-100 sebesar 72,05\% siswa, sedangkan ketuntasan nilai KKM nasional (nilai 75100) sebesar $65,44 \%$ dengan jumlah peserta didik 89 orang.

\section{B. Data Deskripsi Frekuensi dan Distribusi Frekuensi Kelas XI SMA Negeri 2 Unggulan Talang Ubi}

Jika dilihat dari hasil nilai Deskripsi Data Frekuensi Nilai Gabungan Semester Genap Kelas XI SMA Negeri 2 Unggulan Talang Ubi di kelas XI MIPA 1 dan XI MIPA 2 pada gambar 2 berikut:

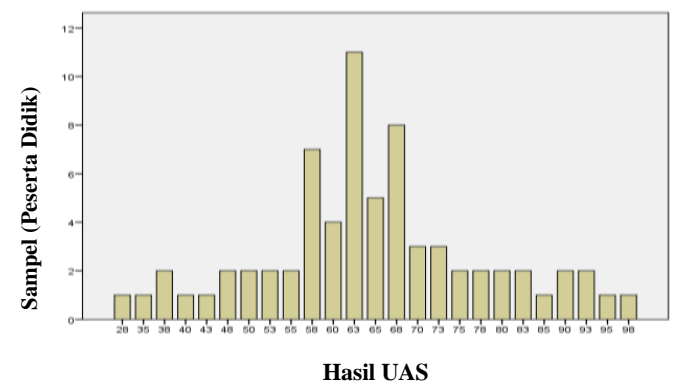

Gambar 2. Hasil Nilai Gabungan Dari Kelas XI MIPA 1 Dan XI MIPA 2

Berdasarkan Gambar 2 menunjukan bahwa nilai biologi kelas XI MIPA 1 dan XI MIPA 2 di SMA Negeri 2 Ungggulan Talang Ubi berada dalam kategori cukup baik dalam ketuntasan belajar yang di buktikan dengan peroleh nilai 28 hingga 98. Nilai paling rendah yaitu 28 sebanyak 1 orang, sedangkan nilai yang paling tinggi yaitu 98 sebanyak 1 orang. Nilai yang paling banyak di peroleh peserta didik yaitu 63 sebanyak 11 orang.

Adapun Distribusi frekuensi menunjukan hasil nilai semester genap dilihat pada Tabel 2 sebagai berikut. 
Tabel 2. Distribusi Frekuensi Hasil Nilai Semester Kelas XI SMA Negeri 2 Unggulan Talang Ubi

\begin{tabular}{|c|c|c|c|}
\hline Kategori & Frekuensi & $\begin{array}{c}\text { Persentase } \\
(\%)\end{array}$ & $\begin{array}{c}\text { Ketera } \\
\text { ngan }\end{array}$ \\
\hline \multicolumn{4}{|c|}{ Nilai KKM Sekolah } \\
\hline $68-100$ & 21 & $30,00 \%$ & Tuntas \\
\hline $0-67$ & 49 & $70,00 \%$ & $\begin{array}{c}\text { Belum } \\
\text { tuntas }\end{array}$ \\
\hline \multicolumn{4}{|c|}{ Nilai KKM Nasional } \\
\hline $75-100$ & 18 & $25,71 \%$ & Tuntas \\
\hline $0-74$ & 52 & $74,28 \%$ & $\begin{array}{c}\text { Belum } \\
\text { tuntas }\end{array}$ \\
\hline
\end{tabular}

Berdasarkan Tabel 2 menunjukan bahwa hasil dari nilai KKM sekolah yang medapatkan ketuntasan dengan presentase $30,00 \%$ dengan jumlah peserta didik 31 orang, sedangkan nilai KKM nasional memiliki persentase ketuntasan $25,71 \%$ dari jumlah peserta didik 36 orang.

\section{Data rata-rata Gabungan hasil nilai belajar di SMA Negeri 1 dan SMA Negeri 2 Unggulan Talang Ubi}

Hasil belajar peserta didik bahwa pada SMA Negeri 1 Talang Ubi nilai ratarata UAS telah mencapai KKM. Sedangkan di SMA Negeri 2 Unggulan Talang Ubi nilai rata-rata UAS belum mencapai KKM dan dapat dilihat pada Tabel 3 berikut.

Tabel 3. Data Rata-Rata Hasil Nilai Semester Genap Kelas XI SMA Negeri 1 dan SMA Negeri 2 Unggulan Talang Ubi

\begin{tabular}{|c|c|c|c|c|}
\hline \multirow{2}{*}{} & \multicolumn{2}{|c|}{ SMA Negeri 1 } & \multicolumn{2}{c|}{$\begin{array}{c}\text { SMA Negeri 2 } \\
\text { Unggulan }\end{array}$} \\
\cline { 2 - 5 } & $\begin{array}{c}\text { Rata- } \\
\text { rata }\end{array}$ & $\begin{array}{c}\text { ketunt } \\
\text { asan }\end{array}$ & $\begin{array}{c}\text { Rata- } \\
\text { rata }\end{array}$ & $\begin{array}{c}\text { Ketunt } \\
\text { asan }\end{array}$ \\
\hline $\begin{array}{c}\text { Hasil } \\
\text { Belajar }\end{array}$ & 75,56 & $80,88 \%$ & 64,64 & $57,86 \%$ \\
\hline
\end{tabular}

Berdasarkan Tabel 3 menunjukan bahwa SMA Negeri 1 Talang Ubi memiliki ketuntasan $80,88 \%$ dengan ratarata nilai UAS 75,56, sedangkan di SMA Negeri 2 Unggulan Talang Ubi memiliki ketuntasan $57,86 \%$ dengan nilai rata-rata 64,64 .

\section{PEMBAHASAN}

\section{A. Hasil Nilai Rata-Rata Semester Genap Mata Pelajaran Biologi Kelas XI SMA Negeri 1 Talang Ubi}

Pada saat belajar online terdapat peningkatan hasil nilai rata-rata belajar semester akhir sesudah dan sebelum pandemi yang dilaksanakan di kelas XI MIPA 1, MIPA 2, MIPA 3, MIPA 4. Nilai sebelum belajar online atau belajar secara tatap muka langsung antara peserta didik dan guru itu mempunyai rata-rata yaitu 33,93 berarti nilai ini sangat rendah dan jauh dari nilai KKM sekolah dan nasional, hal ini disebabkan karena seluruh guru kelas MIPA 1, MIPA 2, MIPA 3, dan MIPA 4 menggunakan soal yang berbentuk pilihan ganda dengan durasi waktu 2 jam tanpa membuka buku atau internet.

Dibandingkan dengan nilai ratarata saat belajar online yaitu 75,56 nilai peserta didik lebih meningkat dan telah mencapai nilai KKM sekolah dan nasional, karena ada beberapa faktor yang menyebabkan naiknya nilai UAS yaitu; (1) saat belajar online ini peserta didik bebas mencari jawaban melalui google atau tanya sama teman untuk mengisi ujian akhir semester genap ini dan peserta didik mengerjakannya memalui jarak jauh dari pantau guru, (2) pada kelas XI MIPA 1 dan XI MIPA 2 menggunakan jenis soal essay dengan durasi waktu 12 jam karena kelas tersebut bisa dikatakan kelas unggulan dan bisa belajar secara mandiri untuk memahami materi, sedangakan kelas XI MIPA 3 dan XI MIPA 4 menggunakan jenis soal pilihan ganda dengan alasan agar memudahkan guru dan peserta didik dan terkendala jaringan dan tempat.

Pada saat belajar online guru dpat menggunakan aplikasi yang dirancang sebaik mungkin menggunakan aplikasi whatsapp, google classroom, dan form office sehingga peserta didik mudah memahami mata pelajaran biologi dengan materi dan pengumpulan tugas yang membuat peserta didik bisa belajar 
walaupun di jarak jauh. Menurut Ashadi (2020) bahwa aplikasi google classroom memungkinkan untuk terciptanya ruang kelas di dunia maya. Selain itu, google classroom bisa menjadi sarana distribusi tugas, submit tugas bahkan menilai tugastugas yang dikumpulkan. Aplikasi ini dapat membantu memudahkan tenaga pendidikan dan peserta didik dalam melaksanakan proses belajar dengan lebih mendalam (Fitra, dkk 2020).

Sedangkan aplikasi whatsapp merupakan salah satu media komunikasi yang digunakan untuk mengirim pesan teks, gambar, suara, lokasi, video, dan dapat membentuk whatsapp group dalam satu kelas dan guru nya. Whatsapp group sangat membantu untuk berkomunikasi jarak jauh dalam pemberian tugas atau informasi (Yensi, 2020; Wilson, 2020; Sadat, 2020).

Metode yang diterapkan guru pada peserta didik saat pandemi yaitu berdiskus, tanya jawab, dan ceramah. Sedangkan model yang digunakan yaitu secara online melalui aplikasi. Strategi yang digunakan dalam mengajar sudah sesuai dengan apa yang direncanakan yaitu menggunakan aplikasi dan buku panduan yang diberikan dari sekolah untuk menunjang lancarnya pembelajaran. Menurut Khorunnisa (2020) strateri pembelajaran merupakan suatu rangkaian kegiatan dalam penggunaan metode belajar dan kegiatan memanfaatkan sumber daya yang menyusun strategi tahap rencana kerja yang belum tertuju pada sebuah tindakan. Pembelajaran biologi selama pandemi yang di ampuh selama dua kali (2x) dalam seminggu, satu kali pertemuan itu mempunyai durasi waktu pengajaran satu jam jadi kalau dua kali (2x) pertemuan itu mempunyai 2 jam dalam satu minggu.

\section{B. Hasil Nilai Rata-Rata Semester Genap Mata Pelajaran Biologi Kelas XI SMA Negeri 2 Unggulan Talang Ubi}

Pada saat pembelajaran online terdapat penurunan sehingga nilai hasil belajar semester akhir tidak mencapai KKM yang dilihat mulai dari kelas XI MIPA 1 dan XI MIPA 2. Nilai sebelum belajar online atau saat belajar tatap muka mempunyai nilai rata-rata yaitu 87,36 nilai yang didapat telah mencapai KKM sekolah maupun nasional. Sedangkan nilai rata-rata saat belajar online yaitu 64.64 nilai peserta didik sangat rendah dan menurun, sehingga tidak mencapai nilai KKM sekolah dan nasional.

Faktor-faktor yang mempengaruhi rendahnya nilai KKM yaitu; (1) jenis bentuk soal yang digunakan pada saat belajar sebelum pandemi dan belajar online sama-sama menggunakan soal pilihan ganda dengan jumlah 40 soal yang hanya memilih salah satu jawaban yang benar. Berdasarkan hasil wawancara pada guru, terdapat faktor penyebab nilai KKM rendah adalah tingkat kesulitan materi yang diajarkan pada saat pandemi dan masih ada beberapa materi juga masih belum terselesaikan secara detail sehingga membuat peserta didik berkurang minat untuk belajar dan merasa kesulit untuk memahami pembelajaran tersebut, (2) durasi yang diberikan guru kepada peserta didik untuk mengerjakan UAS hanya 2 (dua) jam saja sehingga menjawabnya harus cepat dan tepat, (3) belajar online guru tidak memiliki waktu untuk praktikum, guru hanya memberikan tugas dan materi melalui aplikasi whatsapp berupa file berbentuk PDF yang membuat peserta didik harus belajar secara mandiri dan membuat peserta didik merasa bosan, (4) aplikasi yang digunakan untuk UAS yaitu examora yang memudahkan peserta didik untuk menjawab langsung dan peserta didik dapat melihat hasil UAS di aplikasi tersebut

Menurut Yustika (2016) soal pilihan ganda lebih efektif dari segi waktu pembuatan dan untuk kepentingan evaluasi namun tentunyakita harus memperhatikan kualitas pembuatan dan penyajian soalnya. Masalah yang sering timbul dalam pembuatan soal adalah jawaban yang 
kurang tepat daan ketidakpuasan kualitas materi soal.

Aplikasi yang digunakan oleh guru pada saat online yaitu menggunakan aplikasi whatsapp dan examora. Untuk aplikasi whatsapp memberikan tugas dan penjelasan mengenai materi mata pelajaran biologi, sedangkan aplikasi examora untuk mengerjakan ulangan akhir semester genap yang akan melihat hasil nilai akhir belajar peserta didik. Menurut Yensy (2020) whatsapp group sangat membantu untuk berkomunikasi jarak jauh dalam pemberian tugas atau informasi.

Pembelajaran pada saat pandemi guru menerapkan metode dan model yang digunakan dalam pembelajaran biologi pada saat online yaitu secara online yang menyampaikan materi dengan cara berdiskusi, tanya jawab, dan ceramah mengakibatkan tidak sesuai dengan apa yang direncanakan oleh guru tersebut. Karena strategi pembelajaran biologi pada saat itu hanya mendengarkan tanpa ada sumber sumber materi seperti buku dan hanya menggunakan internet saja. Waktu yang diampuh selama seminggu yaitu satu kali (1x) dalam seminggu, satu kali pertemuan itu mempunyai durasi waktu pengajaran 1 (satu) jam jadi dalam satu minggu hanya berkesempatan belajar biologi dan memahami materi pembelajaran dengan jelas hanya $1 \mathrm{x}$ dalam satu minggu. Materi tidak sepenuhnya dijelaskan oleh guru terkait sediktinya pertemuan untuk belajar biologi, sehingga peserta didik hanya belajar secara mandiri di rumah

\section{Hasil Rata-Rata Semester Genap Mata Pelajaran Biologi Kelas XI di SMA Negeri 1 dan SMA Negeri 2 Unggulan Talang Ubi}

Pada hasil nilai rata-rata semester genap mata pelajaran biologi kelas XI di SMA Negeri 1 dan SMA Negeri 2 Unggulan Talang Ubi ada beberapa perbedaan dari hasil nilai rata-rata, aplikasi yang digunakan untuk belajar, banyaknya pertemuan, dan aplikasi yang digunakan guru untuk menyampaikan materi biologi kepada peserta didik.

Perbedaan untuk hasil nilai ratarata di SMA Negeri 1 Talang Ubi sudah mencapai KKM yaitu 75.56 yang ditentukan dari sekolah 67 dan nasional 75, sedangkan SMA Negeri 2 Unggulan Talang Ubi belum mencapai KKM yaitu 64.64 lebih kecil dari yang di tentukan sekolah yaitu 68 dan nasional 75 .

Jenis soal di SMA Negeri 1 Talang Ubi menggunakan soal essay dan pilihan ganda. Nilai siswa SMAN 1 mengalami peningkatan karena tipe soal yang diberikan terbantu dengan soal essai. Jenis soal essai yang diberikan guru hanya pada tingkatan ranah kognitif $\mathrm{C} 1$ seperti menjelaskan, menggambar, menghafal dengan durasi 12 jam. Bentuk soal essai seperti ini sangat mudah menemukan jawaban di internet. Selain itu juga SMAN 1 memberikan soal ujian pilihan ganda ranah kognitif $\mathrm{C} 1, \mathrm{C} 2$, dan $\mathrm{C} 3$ dengan waktu pengerjaan 3 jam. Komponen penilaian yang digunakan guru adalah $50 \%$ dari soal essai dan 50\% dari soal pilihan ganda. Sedangkan di SMA Negeri 2 Unggulan Talang Ubi hanya menggunakan soal pilihan ganda lebih bervariasi dengan tingkat kesukaran soal C1, C2, dan C3 dan durasi hanya 2 jam, sehingga banyak siswa yang mendapatkan nilai di bawah KKM.

Aplikasi yang digunakan antara SMA Negeri 1 dan SMA Negeri 2 Unggulan Talang Ubi juga berbeda, di SMA Negeri 1 Talang Ubi sangat aktif di aplikasi google classroom dan aplikasi whatsapp untuk mengerjakan ulangan akhir semester genap. Sedangkan di SMA Negeri 2 Unggulan Talang Ubi hanya menggunakan aplikasi whatsapp dan aplikasi examora untuk melaksanakan ulangan akhir semester genap.

Menurut (Salamah, 2020 dan Maharani, 2019) menyatakan bahwa kelebihan dari aplikasi google clasroom yaitu; 1) mudah digunakan untuk pengiriman tugas, 2) berbasis cloud bisa digunakan dalam lingkungan belajar karena aplikasi ini mewakilin sebagian 
besar alat komunikasi antar guru dan peserta didik, 3) fleksibilitas aplikasi google classroom ini mudah diakses dan dapat digunakan oleh guru dan peserta didik di lingkungan online, 4) ranah seluler karena aplikasi ini dirancang agar responsif mudah digunakan pada perangkat mobile di mana saja, 5) sangat menghemat waktu.

Metode dan model yang digunakan SMA Negeri 1 dan SMA Negeri 2 Unggulan Talang Ubi sama-sama menggunakan sistem online dengan penyamapaian materinya secara berdiskusi, tanya jawab, ceramah.

Pendidik harus dapat menggunkan metode yang tepat dalam pembelajaran di kelas, baik tepat dengan materi pembelajaran atau kondisi peserta didik. terdapat berbagai bahan ajar interaktif juga dapat meningkatkan diskusi dan keaktifan peserta didik serta sehingga wawasan peserta didik bertambah, materi yang sulit terselesaikan melalui diskusi interaktif Kartini (2020).

Selain itu, strategi pembelajaran biologi jika untuk mejalankan keaktifan dan keefesien berjalannya pembelajaran juga dilihat dari durasi banyaknya pertemuan untuk mengerjakan UAS juga berbeda untuk di SMA Negeri 1 Talang Ubi memiliki durasi waktu mengerjakan yaitu untuk jenis soal essay diberikan waktu 12 jam dan jenis soal pilihan ganda kurang lebih 3 jam, sedangkan di SMA Negeri 2 Unggulan Talang Ubi untuk mengerjakan jenis soal pilihan ganda hanya di berikan waktu 2 jam.

\section{KESIMPULAN}

Perbedaan nilai rata-rata peserta didik SMA Negeri 1 Talang Ubi sudah mencapai KKM sekolah dan nasional yaitu 75,56, sedangkan SMA Negeri 2 Unggulan Talang Ubi belum mencapai KKM yang ditetapkan sekolah dengan nilai yaitu 64,64. Faktor yang sangat mempengaruhi nilai UAS di sekolah yaitu (1) tipe soal ujian akhir semester pada saat belajar online di SMA Negeri 1 menggunakan jenis soal essay (ranah kognitif $\mathrm{C} 1$ ) dan soal pilihan ganda pada ranah kognitif $\mathrm{C} 1$, C2, dan C3. Sedangkan SMAN 2 Unggulan Talang ubi hanya menggunakan jenis soal pilihan ganda pemahaman $\mathrm{C} 1$, C2, dan C3, (2) waktu pengerjaan soal berbeda yaitu lama pengerjaan 12 jam di SMAN 1 dan 2 jam di SMAN 2 Talang Ubi.

\section{SARAN}

Berdasarkan saran dari hasil penelitian dan kesimpulan yang dilakukan pada peneliti yaitu:

1. Disarankan untuk pembelajaran guru lebih mempertimbangakan ketersediaan sarana dan prasarana yang akan digunakan

2. Dalam pelaksanaan pembelajaran guru lebih sering memotivasi peserta didik khususnya kepada peserta didik yang memiliki prestasi akademik rendah dan belum memenuhi kriteria ketuntasan minimal dalam pembelajaran.

3. Dalam kegiatan evaluasi guru harus tetap selalu mempertahankan penyajian soal ujian akhir semester genap yang sudah baik dari sesuai materi dan tingkat kesulitan.

\section{DAFTAR RUJUKAN}

Ashadi, N. R., Sutarsih S. 2020. Hubungan Pemanfaatan Google Clasroom Dan Kemandirian Terhadap Hasil Belajar Mahasiswa PTIK Pada Masa Pandemi. Jurnal Media Elektrik, 17(2) : 46-51.

Fitra, A., Martua, S. Desi, C. P. S, Endra, A. 2020. Pemanfaatan dan Pengelolaan Google Classroom Sebagai Media Pembelajaran dan Pengajaran Dari Bagi Guru-Guru SMP. Jurnal Pengabdi, 3(2) : 101109.

Friatma, A. 2017. Analisis Kualitas Soal Ujian Akhir Semester Genap Mata Pelajaran Biologi Kelas XI IPA SMA Negeri Wilayah Selatan Kabupaten Solok Tahun Pelajaran 
2015/2016. Bioeducation Journal, $1(2): 50-67$.

Hikmah, N. 2016. Peningkatan Hasil Belajar Matematika Tentang Penjumlahan Dan Pengurangan Bilangan Bulat Melalui Alat Peraga Mistar Bilangan Pada Siswa Kelas IV SDN 005 Samarinda Ulu. Jurnal Pendas Mahakam, 1(1) : 80-85.

Kartini, S., H. Widiowati., \& T. Asih. 2020. Pembelajaran Daring Berbasis Metode Team Assisted Individualization (TAI) untuk Optimalisasi Nilai Kognitif Peserta Didik. Jurnal Pendidikan Biologi Bioedukasi 11 (2): 126-130.

Khoirunnisa. 2020. Pembelajaran Online Pada Masa Pandemi Covid19 Sebagai Strategi Pembelajaran dan Capaian Hasil Belajar Pada Siswa Kelas III $B$ MI Al-ITTIHAAD Citrosono Kecamatan Grabag Kabupaten Magelang Tahun Pelajaran 2019/2020. Skripsi. Online. Salatiga: Institut Agama Islam Negeri Salatiga.

Maharani, N. Ketut, S. K. 2019. Penggunaan Google Classroom Sebagai Pengembangan Kelas Virtual Dalam Keterampilan Pemecahan Masalah Topik Kinematika Pada Mahasiswa Jurusan Sistem Komputer. Jurnal Of Science Education, 3(3) : 167-173

Novianti, N. K. D., Santoso, H., Lepiyanto. 2020. Pengaruh Penggunaan Model Pembelajaran Problem Based Instruction (PBI) Terhadap Hasil Belajar Peserta Didik Dalam Pembelajaran Biologi. Jurnal Pendidikan Biologi Uniiversitas Muhammadiyah Metro, 11(2) : 175180.

Nurbudiyani, I. 2013. Pelaksanaan Pengukuran Ranah Kognitif, Afektif, Dan Psikomotor pada mata pelajaran IPS Kelas III SD Muhammadiyah Palangkaraya. Anterior Jurnal, 13(1) : 88-93.
Prasetya, I. T. 2012. Meningkatkan Keterampilan Menyusun Instrumen Hasil Belajar Berbasis Modul Interaktif Bagi Guru - Guru IPA SMP N Kota Malang. Journal of Education Research And Evaluation. Universitas Negeri Semarang, 1(2) : 107-112.

Sadat, F. A. 2020. Penggunaan Platfrorm Google Classroom dan Whastsapp Sebagai Media pembelajaran Daring Pada Masa Pandemi Covid 19. Jurnal Ilmu Pendidikan Islam, 3(1) : 11-18.

Salamah, W. 2020. Deskripsi Penggunaan Aplikasi Google Classroom Dalam Proses Pembelajaran. Jurnal Penelitian dan Pengembangan Pendidikan, 4(3) : 533-538.

Sari, M., Nawawi, Handi, D. 2020. Analisis Pembelajaran di Era Pandemi (Covid-19) Pada program Studi Pendidikan Biologi IKIP PGRI Pontianak. JPTIK, 5(1) : 1-7.

Sari I Y. 2011. Analisis Butir Soal Ulangan Akhir Semester Ekonomi Akuntansi Kelas X1 IPS Semester Genap SMA Negeri 1 Ngaglik Tahun Ajaran 2010/2011. Skripsi. Yogyakarta. UNY.

Yensy, A. N. 2020. Efektifitas Pembelajaran Statistika Matematika Melalui Media Whatsapp Group Ditinjau Dati Hasil Belajar Mahasiswa (Masa Pandemi Covid 19). Jurnal Pendidikan Matematika Raflesia, 5(2) : 65-74.

Yunanti, E. 2016. Hubungan Antara Kemampuan Metakognitif dan Motivasi Belajar Dengan Hasil Belajar Biologi Kelas IX MTS N Metro Tahun Pelajaran 2013/2014. Jurnal Pendidikan Biologi Universitas Muhammadiyah Metro, $7(2): 81-89$.

Yustika, G. P. 2018. Pembelajaran Biologi Melalui Latihan Soal Pilihan Ganda Untuk Siswa SMA. Jurnal Pengabdian Pada Masyarakat, 3(1) : 7-14. 
P. R. AJENG, ASEPTIANOVA, A. KARTIKA, M. ASTRIANI, ANALISIS....

Wilson, A. 2020. Penerapan Metode

Pembelajaran Daring (Online) Melalui Aplikasi Berbasis Android Saat Pandemi Global. Jurnal SAP (Susunan Artikel Pendidikan), 5(1): 66-72. 